\title{
Enamel microabrasion: achieving aesthetic success to dental fluorosis in a single session - one-year follow-up
}

\author{
Cecília Atem Gonçalves de Araújo Costa ${ }^{a}$, Rodrigo Richard da Silveira ${ }^{\mathrm{b}}$, José Carlos Pereira ${ }^{\mathrm{c}}$, \\ Juliano Sartori Mendonçad ${ }^{d}$, Sérgio Lima Santiago ${ }^{\mathrm{e}}$
}

\begin{abstract}
OBJECTIVE: To describe the enamel microabrasion technique used to treat the patient with white stains due dental fluorosis, highlighting the importance of complete anamnesis and clinical examination to achieve the clinical success.

CASE DESCRIPTION: patient's complains, aesthetic self-perception, age, general health, history of excessive intake of fluoride and time of teeth development were considered to the diagnosis and treatment plan. Also, dental trans illumination was used to evaluate the white spots diffusion and estimate the lesion's length. An abrasive paste mixture of equal parts $37 \%$ phosphoric acid and pumice was applied with a wooden spatula in order to perform enamel microabrasion. After the last application, the teeth were polished with finishing discs and a neutral sodium fluoride gel was applied to enamel remineralization. Satisfactory results in the aesthetic improvement were possible with a minimally invasive and cost-effective technique. The dental trans illumination after treatment showed the disappearance of the enamel opacities, preserved on the one-year follow-up.

CONCLUSION: Cosmetic dentistry has been increasingly practiced today. However, a correct aesthetic planning should be based on current restorative dentistry concept. For any type of procedure, the dentist should opt for sound tooth structure preservation. This technique might be an efficient alternative to restorative treatments and can be considered a successful procedure. In cases of esthetic alterations due fluorosis, non-invasive methods such enamel microabrasion should be considered before invasive restorative treatments.
\end{abstract}

Keywords: conservative procedure; dental fluorosis; enamel; white spots.

\section{Microabrasão em esmalte: sucesso estético em fluorose dental em única sessão - um ano de acompanhamento}

\section{RESUMO}

OBJETIVO: Descrever a técnica de microabrasão de esmalte usada para tratar manchas brancas devido à fluorose dentária, destacando a importância da completa anamnese e exame clínico para alcançar o sucesso clínico.

RELATO DO CASO: as queixas do paciente, sua auto percepção estética, a idade, a saúde geral, a história de ingestão excessiva de flúor e o tempo de desenvolvimento dos dentes foram considerados para o diagnóstico e plano de tratamento. A transiluminação dental foi utilizada para avaliar a difusão das manchas e estimar a extensão da lesão. Uma mistura de pasta abrasiva de partes iguais: $37 \%$ de ácido fosfórico e pedra-pomes foi aplicada com uma espátula de madeira para realizar a microabrasão do esmalte. Após a última aplicação, os dentes foram polidos com discos de acabamento e um gel de fluoreto de sódio neutro foi aplicado para remineralização do esmalte. Resultados satisfatórios na melhoria estética foram possíveis com uma técnica minimamente invasiva e econômica. A transiluminação dentária após o tratamento mostrou o desaparecimento das opacidades do esmalte, preservadas no acompanhamento de um ano.

CONCLUSÃO: A odontologia estética tem sido cada vez mais praticada hoje. No entanto, um planejamento estético correto deve basear-se no conceito de que, para qualquer tipo de procedimento, o dentista deve optar pela preservação da estrutura dental sadia. Esta técnica pode ser uma alternativa eficiente aos tratamentos restauradores e pode ser considerada um procedimento bem-sucedido. Em casos de alterações por fluorose, métodos não-invasivos, como microabrasão devem ser considerados antes dos tratamentos restauradores invasivos.

Palavras-chave: procedimento conservador; fluorose dental; esmalte; manchas brancas. a Auxiliary Professor at University of Fortaleza, Fortaleza, Brazil; PhD Student, Faculty of Pharmacy, Dentistry and Nursing, Federal University of Ceará Fortaleza, Brazil

${ }^{5}$ Adjunct Professor, Department of Operative Dentistry, Federal University of Minas Gerais, Belo Horizonte, Brazil

${ }^{c}$ Professor, Department of Operative Dentistry, Endodontics and Dental Materials, University of São Paulo, Bauru, Brazil

Adjunct Professor, Department of Restorative Dentistry, Faculty of Pharmacy, Dentistry and Nursing, Federal University of Ceará, Fortaleza Brazil

e Professor, Department of Restorative Dentistry, Faculty of Pharmacy, Dentistry and Nursing, Federal University of Ceará, Fortaleza, Brazil 


\section{INTRODUCTION}

Esthetically compromised smiles affect the self-esteem and social relationships of patients, leading to a continuing increase in demand for aesthetic treatments in dental offices [1]. Spots are undoubtedly one of the factors most associated with aesthetic complaints. Dark spots on teeth are the major concern of patients; however, white spots can also be a cause of an aesthetically unsatisfactory smile [1].

White stains can have many causes such as hypoplasia, hypocalcification, erosion, tetracycline, trauma, and dental fluorosis. This last one is a developmental disturbance of enamel caused by excessive fluoride on the ameloblasts during enamel formation. This disease changes the refractive of the usually translucent enamel, affecting the color and/or structure of the enamel depending on its severity [2]. The clinical appearance of dental fluorosis is characterized by a spectrum of changes in dental arches distributed symmetrically [3].

Among the various degrees of aesthetic impairment due to fluorosis, "mild lesions" are characterized by few and diffuse opacities on enamel surfaces. In these cases, a microabrasion can be considered a minimally invasive and cost-effective technique $[4,5]$. This technique involves mild acid etching in combination with an abrasive medium application. This method eliminates enamel texture irregularities and discoloration defects and improves the appearance of the teeth $[6,7]$.

Since the first microabrasion technique was employed, changes were made regarding the acid, instruments, and application time, with numerous clinical case studies reported in the literature $[4,5,8,9,10]$.

In this context, the case report describes an enamel microabrasion with an application of a $37 \%$ phosphoric acidpumice paste used to treat a patient with a smile aesthetically compromised by mild dental fluorosis.

\section{CASE REPORT}

A healthy 15-year-old female complained about an aesthetically unsatisfactory smile (Figures 1A-1B). The patient's general health was assessed by an interview that revealed a history of excessive intake of fluoride at the time of teeth development.

Clinical examination was performed using a uniform source of light (provided by a conventional operating dental light system) a mouth mirror, an explorer, and periodontal probe. Dental transillumination (Figure 1C) was used to allow the viewing of diffused opacities on enamel in order to estimate the lesion $[11,12]$. The teeth showed symmetrical patterns of opacities on the enamel, like paper-white areas scattered that seemed to be superficial [13].

Based on anamnesis and clinical examination, the diagnosis of the cause of the white enamel stains was dental fluorosis. Dean's Fluorosis Index (Table 1) [13] was used to classify the spots as mild fluorosis and enamel microabrasion was recommended. The patient and legal guardians were informed of the advantages and limitations of this technique, and then the following clinical procedures were conducted.
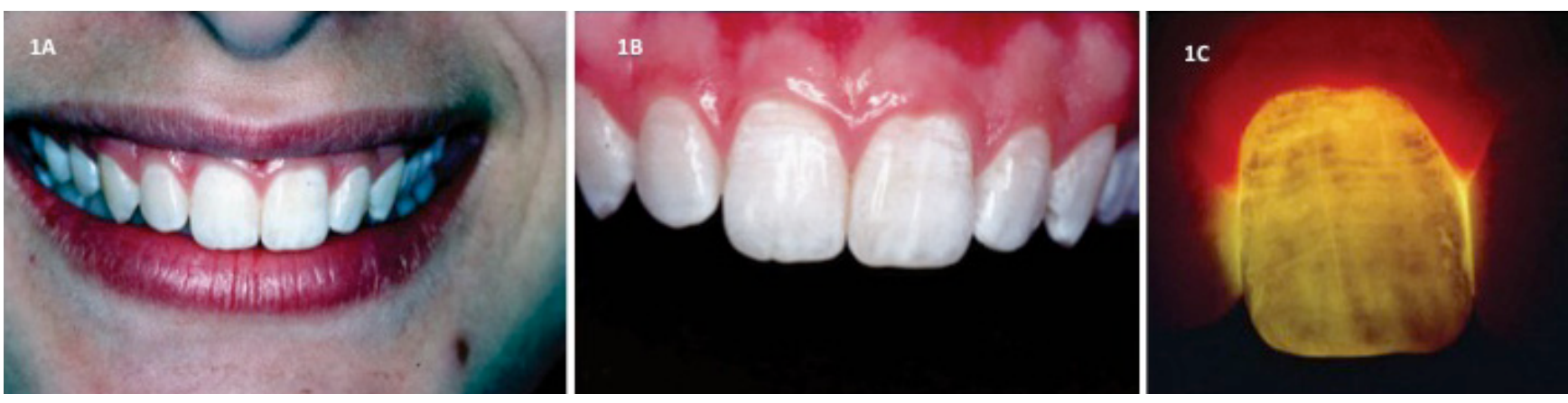

Figure 1. Initial aspect of mild dental fluorosis stains: 1A - smile view; 1B - approximate view; 1C - dental trans illumination showing diffused opacities on enamel.

Table 1. Dean's Fluorosis Index [13]

\begin{tabular}{|c|c|}
\hline Normal & The enamel represents the usual translucent semi vitriform type of structure. The surface is smooth, glossy, and usually of a pale creamy white color \\
\hline Questionable & $\begin{array}{l}\text { The enamel discloses slight aberrations from the translucency of normal enamel, ranging from a few white flecks to occasional white spots. } \\
\text { This classification is utilized in those instances where a definite diagnosis of the mildest form of fluorosis is not warranted and a classification } \\
\text { of "normal" is not justified. }\end{array}$ \\
\hline Very mild & $\begin{array}{l}\text { Small, opaque, paper-white areas scattered irregularly over the tooth but not involving more than } 25 \% \text { of the tooth surface. Frequently included } \\
\text { in this classification are teeth showing no more than about one to } 2 \mathrm{~mm} \text { of white opacity at the tip of the summit of the cusps of the bicuspids } \\
\text { or second molars. }\end{array}$ \\
\hline Mild & The white opaque areas in the enamel of the teeth are more extensive but do not involve as much as $50 \%$ of the tooth. \\
\hline Moderate & All enamel surfaces of the teeth are affected, and the surfaces subject to attrition show wear. Brown stain is frequently a disfiguring feature. \\
\hline Severe & $\begin{array}{l}\text { Includes teeth formerly classified as "moderately severe and severe." All enamel surfaces are affected and hypoplasia is so marked that the } \\
\text { general form of the tooth may be affected. The major diagnostic sign of this classification is discrete or confluent pitting. Brown stains are } \\
\text { widespread and teeth often present a corroded-like appearance. }\end{array}$ \\
\hline
\end{tabular}


After the prophylaxis using a Robinson toothbrush and pumice (SSWhite, Rio de Janeiro, Brazil) a rubber dam (Madeitex, São Paulo, Brazil) was applied to protect the gingival soft tissues (Figure 2A) and a prophylaxis was performed. An acid-pumice abrasive paste was formulated with equal parts of $37 \%$ phosphoric acid (3M ESPE, São Paulo, Brazil) and pumice (SSWhite, Rio de Janeiro, Brazil) (Figures 2B-2C). A small amount of abrasive paste was applied to the buccal surface of each affected tooth and the surfaces were microabraded with a wooden spatula (Estilo Artefatos em madeira, Santa Catarina, Brazil) for 10 (ten) seconds (Figures 2D). The applications were performed with caution to avoid excessive removal of the tooth substrate. A total of 5 (five) applications were done on each tooth or until no stains remained. Between applications, the teeth were washed with water spray for 60 seconds to remove the product and then, air dried in order to assess the aesthetic results. After the last application, the teeth were polished with polishing/finishing discs [7, 14] (Sof-Lex 3M ESPE, São Paulo, Brazil) (Figure 2E) and a 1.23\% neutral sodium fluoride gel (Nupro, Dentsply, Petrópolis, Brazil) was applied for 1 (one) minute to enamel remineralization (Figure 2F) [7,14]. Figures $\mathbf{3 A}$ and $\mathbf{3 B}$ presents the final clinical appearance after treatment. The dental transillumination after treatment (Figure 3C) showed the disappearance of the enamel opacities Figures 4A and 4B present the one-year follow-up.
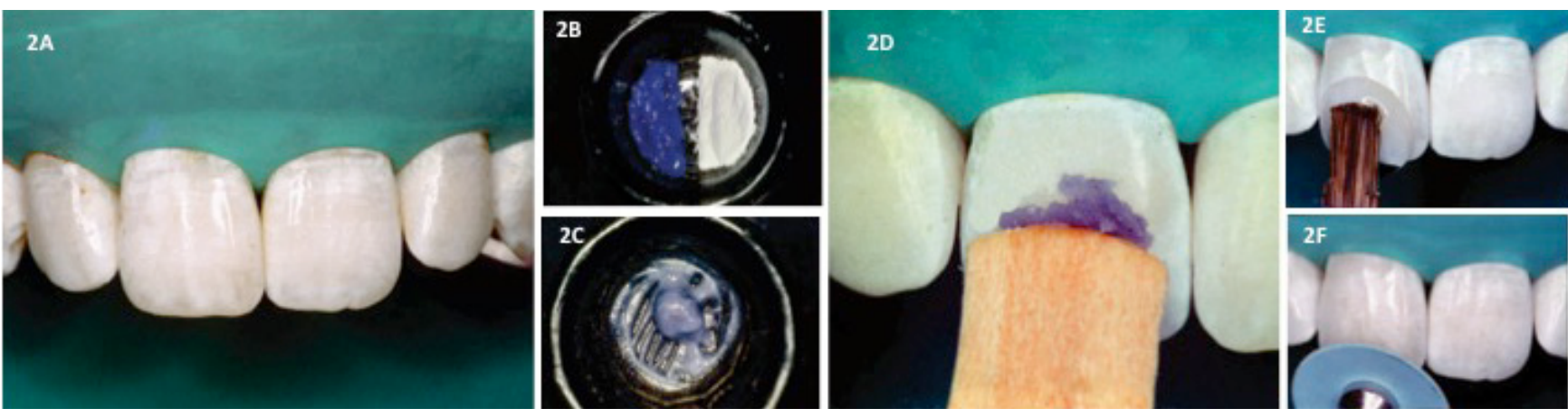

Figure 2. Paste preparation and enamel microabrasion: $\mathbf{2 A}$ - equal parts of $37 \%$ phosphoric acid and pumice; $2 \mathrm{~B}$ - abrasive paste; $\mathbf{2 C}$ - rubber dam applied to protect the gingival soft tissues; $2 \mathrm{D}$ - abrasive paste and wooden spatula; $\mathbf{2 E}$ - final polish after the last application (polishing/ finishing discs); $2 \mathrm{~F}$ - neutral sodium fluoride gel application to enamel remineralization.
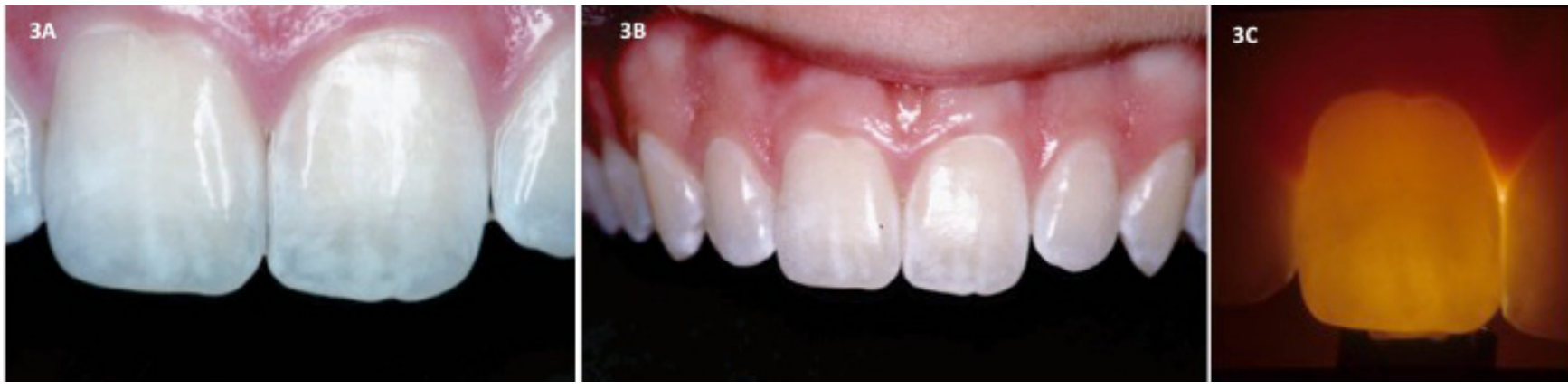

Figure 3. Final clinical appearance after treatment: $(3 \mathrm{~A})$ and $(3 \mathrm{~B})$ immediate results; $(3 \mathrm{C})$ dental trans illumination after treatment shows the disappearance of the enamel opacities.
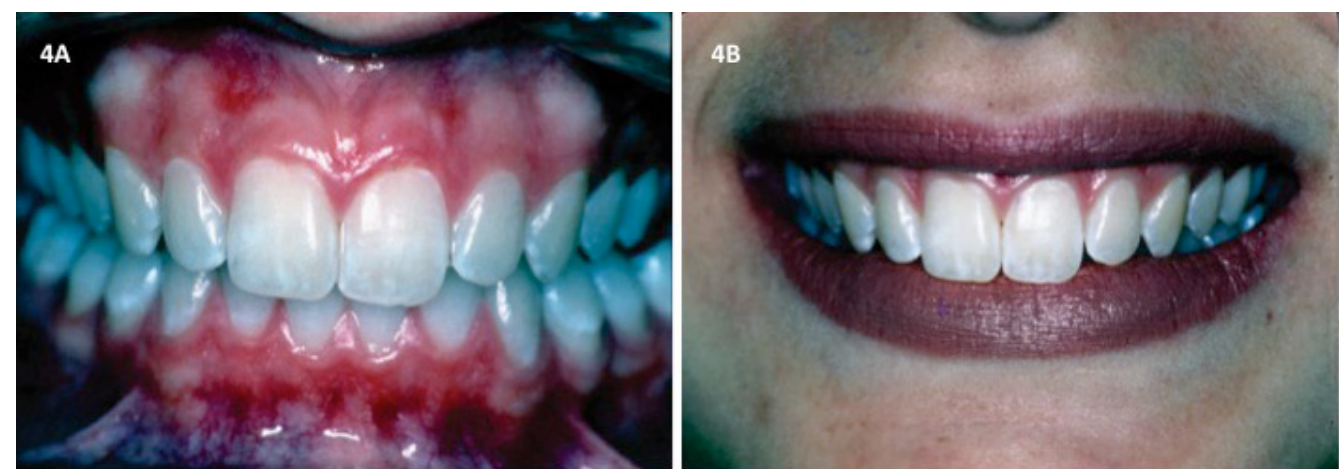

Figure 4. Clinical aspect after one-year follow-up: $4 \mathrm{~A}$ - approximate view; $4 \mathrm{~B}$ - smile view. 


\section{DISCUSSION}

Despite presenting a well-established technique, this paper emphasizes two important considerations to be made before establishing an aesthetic treatment plan. The first is the management in accordance with that which recommends current Restorative Dentistry. For any type of procedure, the professional must always opt for conservative treatment, with greater preservation of healthy tooth structure. The second is the adequacy of the treatment plan to the specific aesthetic needs of each patient. In a dental age marked by major technological advances in aesthetic restorative dentistry, not all patients require more invasive procedures and moreover, not all the techniques available today are financially accessible to all patients.

This article describes this technique of microabrasion used to treat a patient with an aesthetically compromised smile by opaque white spots due to dental fluorosis. With the correct stains management, the results were achieved in one single session and showed effective after one-year follow up. This cost-effective technique with satisfactory aesthetic results is described in literature as a highly satisfactory, safe, and effective procedure [15].

This technique claims to remove the outermost layer of enamel and change the optical properties of the enamel surface. When the enamel surface is abraded with an acid gel, a densely compacted prism-free layer is formed. This prism-free layer reflects and refracts light in such a way that underlying stains are believed to be camouflaged [4]. Rodrigues, et al. [16] showed that $120 \mathrm{~s}$ of microabrasive treatment reduces approximately $10 \%$ of the enamel thickness. Other studies which reviewed the short-and long-term effects indicate that this type of treatment does not weaken the enamel surface since the amount of enamel removed can be considered irrelevant [16].

Microabrasion for stain removal has been described in different ways in the literature over the years and was first described as using hydrocloridric acid [4]. However, this case report describes an enamel microabrasion with a phosphoric acid-pumice paste recommended by Mondelli et al. [10] They suggested mixing 37\% phosphoric acid with extra-fine pumice in equal proportions as an alternative to chloridic acid for the enamel microabrasion [5].

No differences have been found in literature regarding the two acids $[17,18]$. In a split-mouth study design, both acids improved similar aesthetic indices in fluorotic teeth [19]. In the present study, enamel microabrasion using phosphoric acid-pumice was found to be effective. A randomized clinical trial [20] also concluded that this technique was effective in reducing the enamel fluorosis staining. Moreover, because it is not an expensive product, it is easily accessible to professionals, and it is a well-known and commonly used acid in adhesive procedures used by dentists, the microabrasion technique with phosphoric acid is easily applied to clinical use. Undoubtedly, the technique has become accessible for any dentist, since it does not require a specific commercial product.
Concerning the mechanisms and/or instruments used to provide microabrasion, the choice was the wooden spatula and this is in agreement with other case reports described in literature [5]. According to Nahsan et al. [5], this technique promotes diminished wear and although slower it is more controlled when compared to mechanical techniques using rotary slow-speed hand-pieces with rubber cups. This last technique produces more dirt and a higher risk of accidents with spills of acidic paste, and it primarily promotes the best control of the area of ground enamel, preserving sound dental tissue.

However, there is a consensus that regardless of the acid/abrasive material used, much care should be exercised to preserve as much enamel thickness as possible [15]. Because of this, the complete removal of abrasive paste, washing, drying and incisal observation were indispensable to assess the wear already achieved between applications [5]. The severity of the enamel staining determined only five applications $[4,11,14]$.

Enamel microabrasion is considered a conventional method for the management of dental fluorosis but several other techniques have been proposed: bleaching, composite resin restoration, and prosthetic approaches. Recently, resin infiltration has also become a popular technique for the management of dental fluorosis [21].

Aesthetics for humans is a highly subjective concept and the evaluation of the patient's expectations should be considered. Thus, although patients reporting a major satisfaction when home bleaching experienced associated enamel abrasion [20], for this patient, no such association was required with dental bleaching. Mega-abrasion, adhesive resin composite restorations $[22,14,11]$ and/or even resin infiltration [21] were also not necessary. Furthermore, nowadays, the patients are interested in the least invasive and most cost-effective treatments to change their smile. In this case, due to the patient's age, she was not interested in treatment options that involved significant removal of tooth structure, such as porcelain or composite resin veneers.

This case report shows the satisfactory aesthetic results directly related to the location and depth of the spots [22]. Since it is a conservative technique, it has a great clinical relevance, with minimal removal of enamel that can restore the aesthetics of the teeth and enhance the self-esteem of the patient in a single session. The entire process takes less than an hour, it's permanent, with low cost and it is safe for professionals and patients.

Although the transillumination $[11,12]$ could not access the deeper lesions, this conventional method was efficient on enamel hypoplasia detection. The comparison of both periods (before and after enamel microabrasion) confirmed the visual inspection of changes and confirmed the treatment results.

In this context, the dentist must be able to diagnose fluorosis properly and treat it efficiently. If the stains are present in the outer layers of enamel, they can be easily removed, leaving a smooth, glassy enamel. 


\section{CONCLUSION}

This technique may be considered as a micro invasive treatment of white spots created by fluorosis. It also allows for the recovery of the natural tooth appearance and it is a conservative, minimally invasive, less-expensive technique than the other conventional restorative approaches.

\section{REFERENCES}

1. Benbachir N, Ardu S, Krejci I. Indications and limits of the microabrasion technique. Quintessence Int 2007;38(10):881-5.

2. Denbesten P, Li W. Chronic fluoride toxicity: dental fluorosis. Monogr Oral Sci 2011;22:81-96. https://doi.org/10.1159/000327028

3. Guedes-Pinto AC, Bönecker M, Rodrigues CRMD. Pediatric Dentistry Fundamentals. São Paulo: Editora Santos; 2009

4. Croll TP. Enamel microabrasion: observations after 10 years. J Am Dent Assoc 1997;12(8):45-50. https://doi.org/10.14219/jada.archive.1997.0424

5. Nahsan FPS, Da Silva LM, Baseggio W, et al. Conservative approach for a clinical resolution of enamel white spot lesions. Quintessence Int 2011;42(5):423-6.

6. Croll TP. Enamel Microabrasion: the technique. Quintessence Int 1989; 20(6):395-400

7. Sundfeld HS, Croll TP, Briso ALF, De Alexandre RS, Neto DS. Considerations about enamel microabrasion after 18 years. Am J Dent 2007;20(2):67-72.

8. Croll TP, Helpin, ML. Enamel Microabrasion: A New Approach. J Esthet Dent 2000;12(2):64-71. https://doi.org/10.1111/j.1708-8240.2000. tb00202.x

9. Loguercio AD, Correia LD, Zago C, Tagliari D, Neumann E, Gomes OMM Barbieri DB, Reis A. Clinical effectiveness of two microabrasion materials for the removal of enamel fluorosis stains. Oper Dent 2007;32(6):531-8.

10. Mondelli J, Mondelli RFL, Bastos MTAA, Franco EB. Microabrasion with phosphoric acid [in Portuguese]. Rev Bras Odontol 1995;52:20-2.

11. Sundfeld RH, Sundfeld-Neto D, Machado LS, Franco LM, Fagundes TC Briso AL. Microabrasion in tooth enamel discoloration defects: three cases with long-term follow-ups. J Appl Oral Sci 2014a;22(4):347-54. https://doi. org/10.1590/1678-775720130672

12. Wilder-Smith P, Holtzman J, Epstein J, Le A. Optical diagnostics in the oral cavity: an overview. Oral Dis 2010;16(8):717-28. https://doi.org/10.1111/ j.1601-0825.2010.01684.x
13. Mohamed AR, Thomson WM, Mackay TD. An epidemiological comparison of Dean's index and the developmental defects of enamel (DDE) index. J Public Health Dent 2010;70(4):344-7. https://doi.org/10.1111/j.17527325.2010.00186.x

14. Sundfeld RH, Franco LM, Gonçalves RS, de Alexandre RS, Machado LS, Neto DS. Accomplishing esthetics using enamel microabrasion and bleaching- a case report. Oper Dent 2014b;39(3):223-7. https://doi org/10.2341/13-002-S

15. Pini NI, Sundfeld-Neto D, Aguiar FH, et al. Enamel microabrasion: An overview of clinical and scientific considerations. World J Clin Cases 2015;3(1):34-41. https://doi.org/10.12998/wjcc.v3.i1.34

16. Rodrigues MC, Mondelli RF, Oliveira GU, Franco EB, Baseggio W, Wang L. Minimal alterations on the enamel surface by micro-abrasion: in vitro roughness and wear assessments. J Appl Oral Sci 2013;21(2):112-7. https://doi.org/10.1590/1678-7757201302117

17. Bertoldo C, Lima D, Fragoso L, Ambrosano G, Aguiar F, Lovadino J. Evaluation of the effect of different methods of microabrasion and polishing on surface roughness of dental enamel. Indian J Dent Res 2014;25:290-3. https://doi.org/10.4103/0970-9290.138308

18. Sheoran N, Garg S, Damle SG, Dhindsa A, Opal S, Gupta S. Esthetic management of developmental enamel opacities in young permanent maxillary incisors with two microabrasion techniques-a split mouth study. J Esthet Restor Dent 2014;26(5):345-52. https://doi.org/10.1111/jerd.12096

19. Bassir MM, Bagheri G. Comparison between phosphoric acid and hydrochloric acid in microabrasion technique for the treatment of dental fluorosis. J Conserv Dent 2013;16(1):41-4. https://doi.org/10.4103/09720707.105297

20. Castro KS, Ferreira AC, Duarte RM, Sampaio FC, Meireles SS Acceptability, efficacy and safety of two treatment protocols for dental fluorosis: a randomized clinical trial. J Dent. 2014;42(8):938-44. https:// doi.org/10.1016/j.jdent.2014.01.011

21. Auschill TM, Schmidt KE, Arweiler NB. Resin infiltration for aesthetic improvement of mild to moderatr fluorosis: a six-month follow-up Case report. Oral Health Prev Dent. 2015;13(4):317-22.

22. Celik EU, Yildiz G, Yazkan B. Comparison of enamel microabrasion with a combined approach to the esthetic management of fluorosed teeth. Oper Dent 2013;38(5):134-43. https://doi.org/10.2341/12-317-C 